\title{
MAKING MEANING(S) WITH COVER DESIGNS
}

Yvonne Reed

University of the Witwatersrand

In this article Halliday's systemic functional grammar, Kress and Van Leeuwen's grammar of visual design and Bernstein's work on pedagogic discourse are drawn on in order to analyze some of the ways in which meanings are made and some meanings privileged over others in the designing, both visual and discursive, of the covers of three course books prepared for teacher education programmes in South Africa. The primary aim of this analysis is to understand what meanings are offered to readers as entrants into or as established members of communities of practice in the teaching profession and the academy.

Keywords: coursebook cover designs; positioning; communities of practice; teacher education

\section{INTRODUCTION}

Lea argues that in higher education 'certain ways of making meaning are privileged to the exclusion of others within the academy' (2005:188). This article first outlines elements of an analytic framework which may be useful for understanding the meanings offered in the visual and linguistic designs of texts prepared for distance learning programmes in higher education. In the second part of the article the covers of three course books designed for teacher education programmes in South Africa are analysed. Two of these course books are from programmes which have received national recognition for excellence in design ${ }^{1}$ and the third was designed and co-produced by the South African Institute of Distance Education (SAIDE), internationally recognised for the quality of its research and development work in distance education ${ }^{2}$. The analysis of the covers is part of a larger project which aims to offer a critical pedagogic textual analysis of selections from the material 'between the covers' in the three course books.

\section{THE ANALYTIC FRAMEWORK}

In order to develop a framework for the analysis of the cover designs (and also of the pages within the texts that are not the subject of this article) I have drawn on the work of theorists who have a common interest in text in social context. Gunther Kress and Theo van Leeuwen (1996; 2006) have developed fromeworks for 'reading images' on the page or screen. Michael Halliday $(1978 ; 1985)$ and those who have built on his foundational work in systemic functional linguistics (e.g. Martin and Rose, 2003) have developed a model of language which enables us to identify different fnctions of language and how these are realised in spoken or 
written texts to offer particular meanings to listeners or readers. Basil Bernstein's theorization of pedagogic discourse (1996) enables the 'uncovering' of a range of discourses that contribute to meaning making in curriculum documents, teaching materials and classroom learning events. I argue that, in combination, the contributions of these theorists enable designers and evaluators of teaching materials to undertake a critical pedagogic analysis of materials in order to understand the subject positions that are offered to readers.

\section{Analysing the visual elements in the cover designs}

If we are to understand the way in which vital text-producing institutions like the media, education and children's literature make sense of the world and participate in the development of new forms of social stratification, a theory of language is no longer sufficient and must be complemented by theories which can make principles of the new visual literacy explicit...

(Kress \& Van Leeuwen, 2006:179).

In Kress and Van Leeuwen's 'grammar of visual design' $(1996,2006)$ spatial composition is an overarching code 'whose rules and meanings provide the multimodal text with the logic of its integration' (Kress \& van Leeuwen, 2006:177). These authors discuss composition in terms of three interrelated systems: information value; salience and framing.

They argue that the placement of elements in a composition endows them with specific information value. They hypothesise that 'meanings' attach to the vertical and horizontal structuring of a page (as summarised in Figure 1 below) or to a central / peripheral structuring and note that such structures are ideological in that they might not correspond to what is the case for either the producer or the consumer of the image:

The important point is that the information is presented as though it had that status or value for the reader, and that readers have to read it within that structure, even if that valuation may then be rejected by a particular reader.

(Kress \& van Leeuwen, 2006:181).

Figure 1: The information structure of a vertical / horizontal page (based on Kress \& Van Leeuwen, 2006: 179-193)

\begin{tabular}{|l|l|}
\hline $\begin{array}{l}\text { Top left } \\
\text { the ideal } \\
\text { highly valued } \\
\text { given information } \\
\text { medium salience }\end{array}$ & $\begin{array}{l}\text { Top right } \\
\text { the ideal } \\
\text { highly valued } \\
\text { new information } \\
\text { high salience }\end{array}$ \\
$\begin{array}{ll}\text { Bottom left } \\
\text { the real } \\
\text { less valued } \\
\text { given information } \\
\text { low salience }\end{array}$ & $\begin{array}{l}\text { Bottom right } \\
\text { the real } \\
\text { less valued } \\
\text { new information } \\
\text { medium salience }\end{array}$ \\
\hline
\end{tabular}

Kress and van Leeuwen argue that 'viewers of spatial compositions are intuitively able to judge the 'weight' of the various elements of a composition, and the greater the weight of an 
element, the greater its salience' (2006: 202). Salience, or prominence, is the result of a complex interaction of such elements as size, sharpness of focus, colour contrast, placement in the foreground or background and what they refer to as 'culture specific factors such as the appearance of a human figure or a potent cultural symbol' (2006:202). The elements in the composition 'are made to attract the viewer's attention in different degrees' (2006:177). A spatial composition sets up a reading path for a hypothetical reader / viewer which begins with the most salient elements of the composition. However, this does not mean that all readers will follow this path. As Kress and Van Leeuwen observe, in many contemporary texts the image may be most salient but a reader oriented to 'older literacy' may first pay attention to the verbal text:

Framing refers to the ways in which elements in a spatial composition are marked off from or connected to each other by features such as frame lines, white space between elements or changes of colour. (Kress \& Van Leeuwen, 2006: 204).

While the spatial composition of a book cover influences how it is likely to be read, so too do the image choices. Kress and van Leeuwen suggest that visual communication has several resources for constituting and maintaining the interaction between the producer and the viewer of an image. They describe three systems of interactive meaning: contact, social distance and attitude. The system of contact is used to understand the ways in which an image acts on a viewer either by demanding a response or by offering information. The system of distance is used to understand the imaginary relation between represented participants and the viewer and can be considered along a continuum from close up (intimate or personal social distance), to arms' length (social distance) to the public distance of strangers (impersonal distance). Macken-Horarik (2004) describes two systems within the system of attitude outlined by Kress and van Leeuwen. In an image there is 'a horizontal dimension, which creates viewer involvement (through frontality) or detachment (through obliqueness), and a vertical dimension, which creates a relation of power between viewer and represented participants (hierarchical or solidary)' (Macken-Horarik, 2004: 12). The three (contact, distance and attitude) are simultaneous systems: 'any image must either be a 'demand' or an 'offer' and select a certain size of frame and select a certain attitude' (Kress and Van Leeuwen, 2006:148).

\section{Analysing the language in the cover designs}

The grammatical tools used to analyse the language of the covers are drawn from systemic functional linguistics (Halliday, 1978, 1985; Martin \& Rose, 2003). Halliday argues that 'language is as it is because of the functions it has evolved to serve in people's lives' (1978: 4). He describes these functions as (i) representing experience to one another - the experiential or ideational metafunction; (ii) enacting social relationships - the interpersonal metafunction; (iii) organizing these representations and enactments as meaningful text - the textual metafunction. Any clause in a spoken or written text fulfils each of these functions simultaneously. The annotations of the covers (Figures 2 to 7 below) include reference to the designers' use of elements of the grammatical system to realise these functions.

In the literature on identity/subjectivity, discourse has a central role in the constitution of subjectivities: 
... it is this business of how we are constituted, made subject - a business in which the implication of texts and discourses, of bodies and behaviors cannot be underestimated, that we need to understand. (Threadgold, 2001:217)

Lillis and McKinney offer a succinct summary of three broadly distinguishable approaches to language analysis, each of which can be referred to as discourse analysis: 'the analysis of stretches of language longer than a single utterance or sentence; the analysis of specific ways of using language in particular contexts; and the analysis of different ways of representing social reality through language' (Lillis \& McKinney, 2003:.67). For Martin and Rose, discourse analysis 'employs the tools of grammarians to identify the roles of wordings in passages of text, and employs the tools of social theorists to explain why they make the meanings they do' (2003:4).

(Bourdieu, 1991:76) argues that a discourse

...can only exist in the form in which it exists, so long as it is not simply grammatically correct but also, and above all, socially acceptable, i.e. heard, believed and therefore effective within a given state of relations of production and circulation.

Thus discourse analysis must take into account 'the laws defining the social conditions of acceptability of a discourse' (Bourdieu, 1991:76). For Foucault (1990), power and knowledge are joined together in discourse (Foucault, 1990:100). Within a discipline or field of knowledge, competing and sometimes contradictory discourses may be involved in producing particular 'regimes of truth' and particular subjects. For example, some education discourses in South Africa constitute teachers on the one hand as active inventors of a new educational vision for South Africa and on the other as professionally inadequate (Adler in Adler \& Reed, 2002:7-8). While it is important to acknowledge that 'discursive positions offered or invited are not necessarily positions accepted' (Simon, 1992:92), in teacher education materials the voices of authority may be difficult to resist.

In Pedagogy, Symbolic Control and Identity, Bernstein (1996) describes and discusses what he terms 'pedagogic discourse' - a discourse in which instructional discourse (a discourse of mediated knowledges and skills of various kinds and of their relationship to each other) is embedded in regulative discourse (a discourse of social order). $\mathrm{He}$ argues that pedagogic discourse is constructed by a 'recontextualising principle which selectively appropriates, relocates, refocuses and relates other discourses to constitute its own order' (1996:46). It is a discourse that selectively creates 'imaginary subjects':

As pedagogic discourse appropriates various discourses, unmediated discourses are transformed into mediated, virtual or imaginary discourses (1996:47).

In education, Bernstein distinguishes between 'an official recontextualising field (ORF) created and dominated by the state and its selected agents and ministers' and 'a pedagogic recontextualised field (PRF)' consisting of teachers and education researchers (1996:48). I argue that designers and producers of distance education materials for teacher education in South Africa are located primarily in the PRF as mediators of texts - some of which are located in the ORF (for example, Department of Education statements on outcomes-based education) and some of which are located in disciplinary discourses. However, the teachers 
who read the materials will engage in further pedagogic recontextualisation. I am interested in whether particular texts encourage such further recontextualisation - in Bernstein's terms, whether the mediated discourses promote teacher autonomy (social agency). In the rest of this article I attempt to 'uncover' some of the subject positions offered to pre- and in-service teachers by the designers' choices of composition, images and language for the covers of three texts. The first part of the analysis is presented in the form of annotations (with acknowledgement to Alder, 2004) on a reduced-size, black and white version of each cover (Figures 2 to 7 ). 
Figure 2: The front cover of Language in Learning and Teaching (LILT)

Schematic drawing, limited colour contrast and position lower the salience of the image. Knowledge as the 'outcome' of construction accords with current curriculum policy

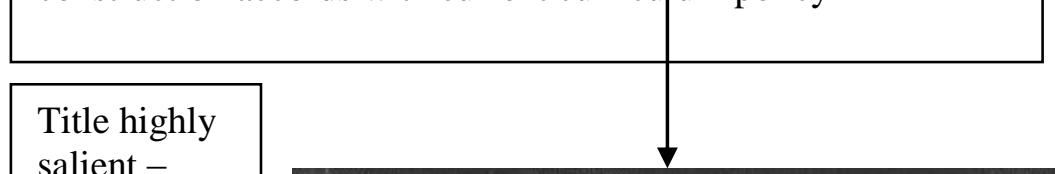

Publishers'names made highly salient by placement \& framing salient foregrounds learners in line with discourse of learnercentred classrooms

To make meaning from the drawing, readers need knowledge of scaffolding in relation to both constructing buildings \& knowledge.

\begin{tabular}{l|l} 
knowledge. \\
Direction of \\
pointing \\
finger \& of \\
learners' \\
movements \\
is towards \\
knowledge - \\
images \\
represent a \\
process. \\
$\begin{array}{l}\text { Teacher } \\
\text { gazes at the } \\
\text { viewer: look } \\
\text { at me \& } \\
\text { what I'm } \\
\text { achieving - } \\
\text { but in } \\
\text { position of } \\
\text { low salience }\end{array}$
\end{tabular}




\section{Figure 3: The back cover of Language in Learning and Teaching (LILT)}

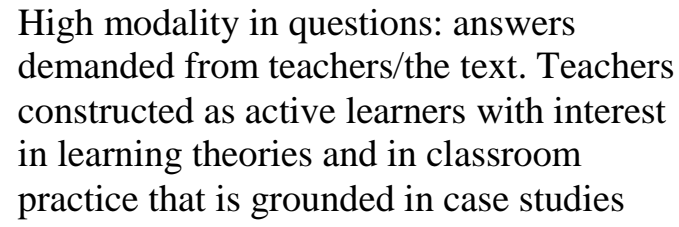

High modality in questions: answers demanded from teachers/the text. Teachers constructed as active learners with interest in learning theories and in classroom practice that is grounded in case studies

'Selling' the text - adjectives 'definitive', 'essential' 'creative' express attitude; teachers positioned as required to read a previous module in the series

\section{SAIDE OXFORD
Learning Guide}

How do learners move from the known to the unknown? What is the significance of school learning? What is the role of the teacher in producing and improving learning? Learners and Learning is the fourth module in the Study of Education series, and it aims to enable teachers to analyse learning and reflect on what they can do to improve it. It draws on the learning theories of various writers, including Piaget and Vygotsky, and grounds these in examples, practical exercises, and case studies drawn from schools. This module includes an interactive Learning Guide, a Reader, and an audiotape.

The Study of Education series is a project of the South African Institute for Distance Education (SAIDE). Aimed at formal and informal teacher education, this series presents valuable open-learning materials for use in distance education or in face. to-face teaching. Intended for use in colleges of education at diploma level these modules may also be used with additional readings in higher or postgraduate diploma courses.

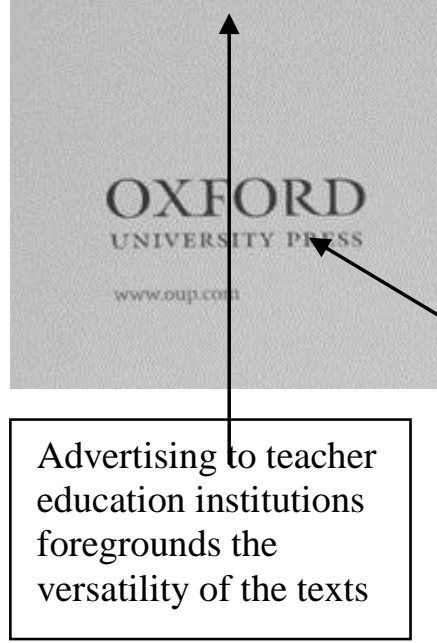

A commercial publisher strongly linked to a prestigious academic institution made salient by font size, colour contrasts \& empty space around the name
What users said about Module 1: Understanding Outcomes-based Education

The definitive work on owe in South Africa ... has attracted considerable interest from other countries implementing OBE ... this is essential reading for any educator who wants to understand osk The Edikuters wike

An example of creative education ... the layout excited me ... the reader's opinion is invited ... easy conversational style this package is comprehensive, relevant and accessible' The rondis

This text is a unique contribution to the field ... it is an exemplar of the activity based, learner-centred approach of outcomes-based education

'Marvellous ... this is just what we need'

Also available in this series Using Modia in Thaching Gretins Printicul: Learect-Centrot and Outcemtes-Basod Thaching

ISBN 019578065

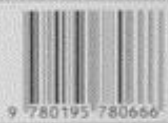

Southem Afric:

\section{$\sqrt{2}$}

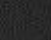

Endorsements from teacher newspapers

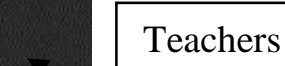

positioned

as needing

easy, accessible

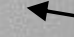

High modality

- authoritative endorsements from senior Education Department bureaucrats

Advertising of other texts in the series 
Figure 4: The front cover of Umthamo 1

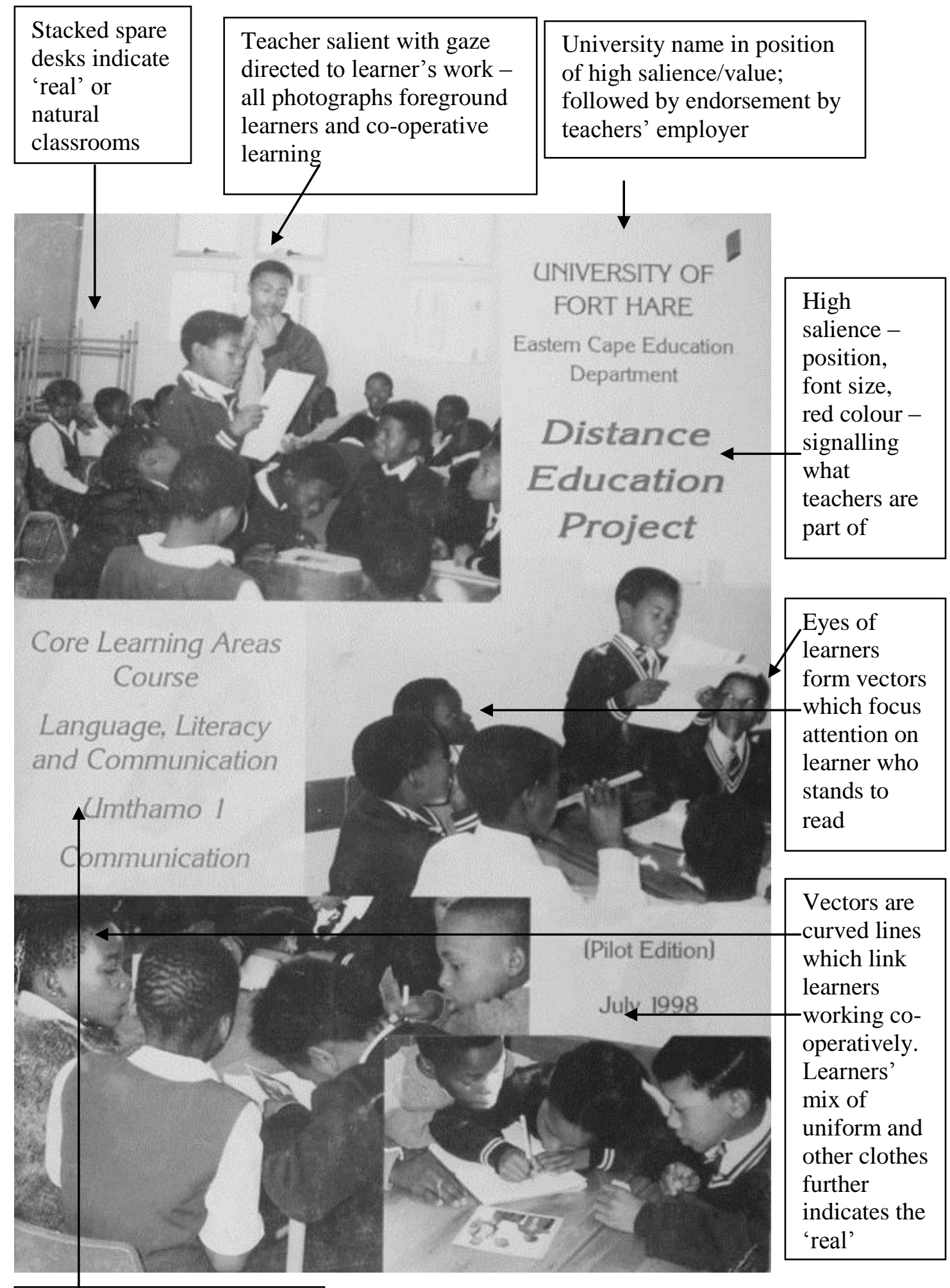

Xhosa word meaning 'bite sized chunk' signals connection with teachers' home language - text is local and manageable
All photographs are medium shots - the viewer looks at learners from a 'teacher distance'. Overlapping photographs contribute to impression of a whole classroom of active learners. 


\section{Figure 5: The back cover of Umthamo1}

If read as part of a pre-reading familiarisation activity, content would be 'new': what the reader is expected to attend to. If read as a post-reading activity it could be read as concluding or summarising 'the given'. Within the text such content would be mediated

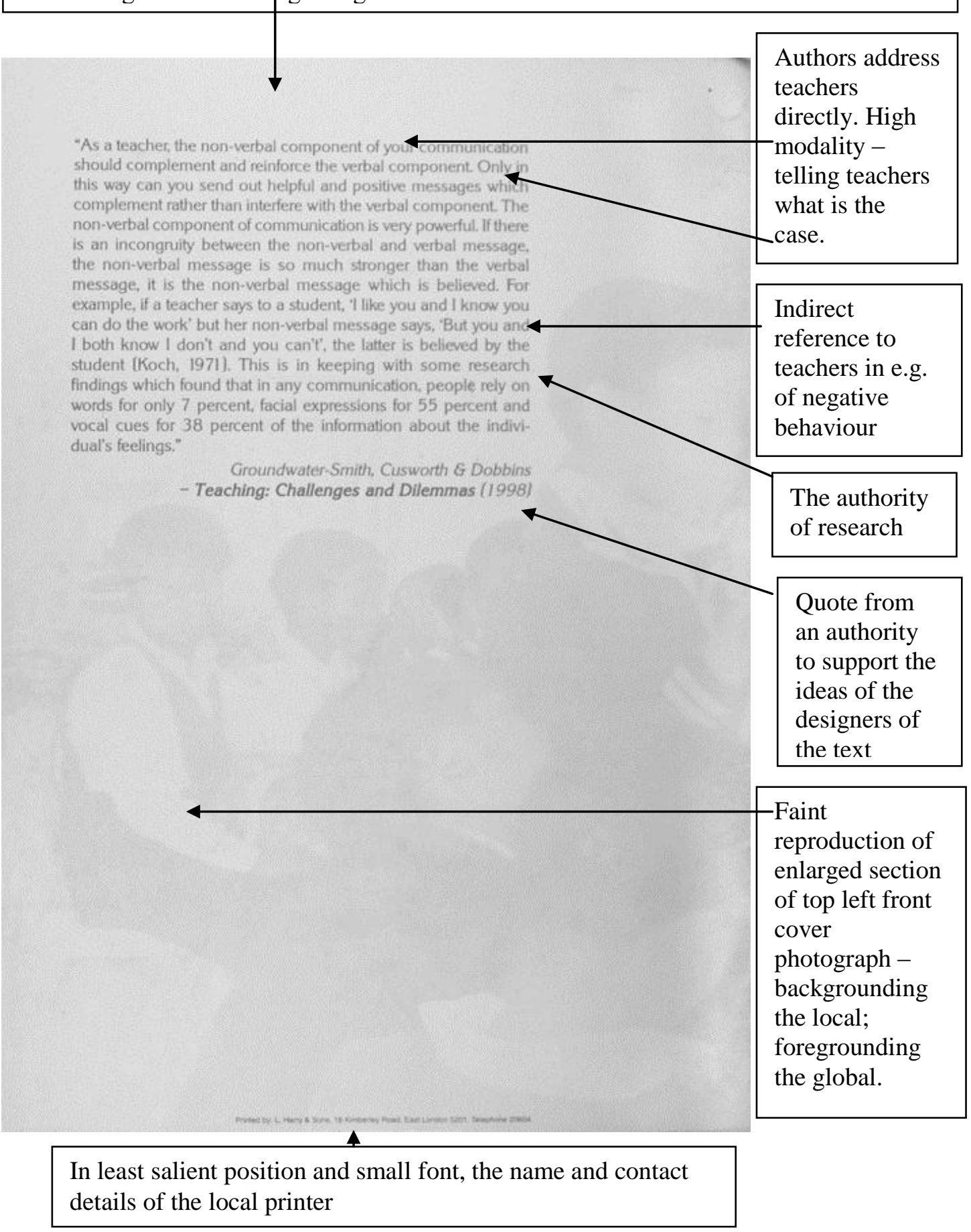




\section{Figure 6: The front cover Learners and Learning}

Highly salient mortar board image; frontal angle encodes involvement with it; highly contrasted blue background \& white brush strokes constitute high modality - certainty of success; framing lines draw the eye to the image. The offer: a degree with both symbolic and economic value.

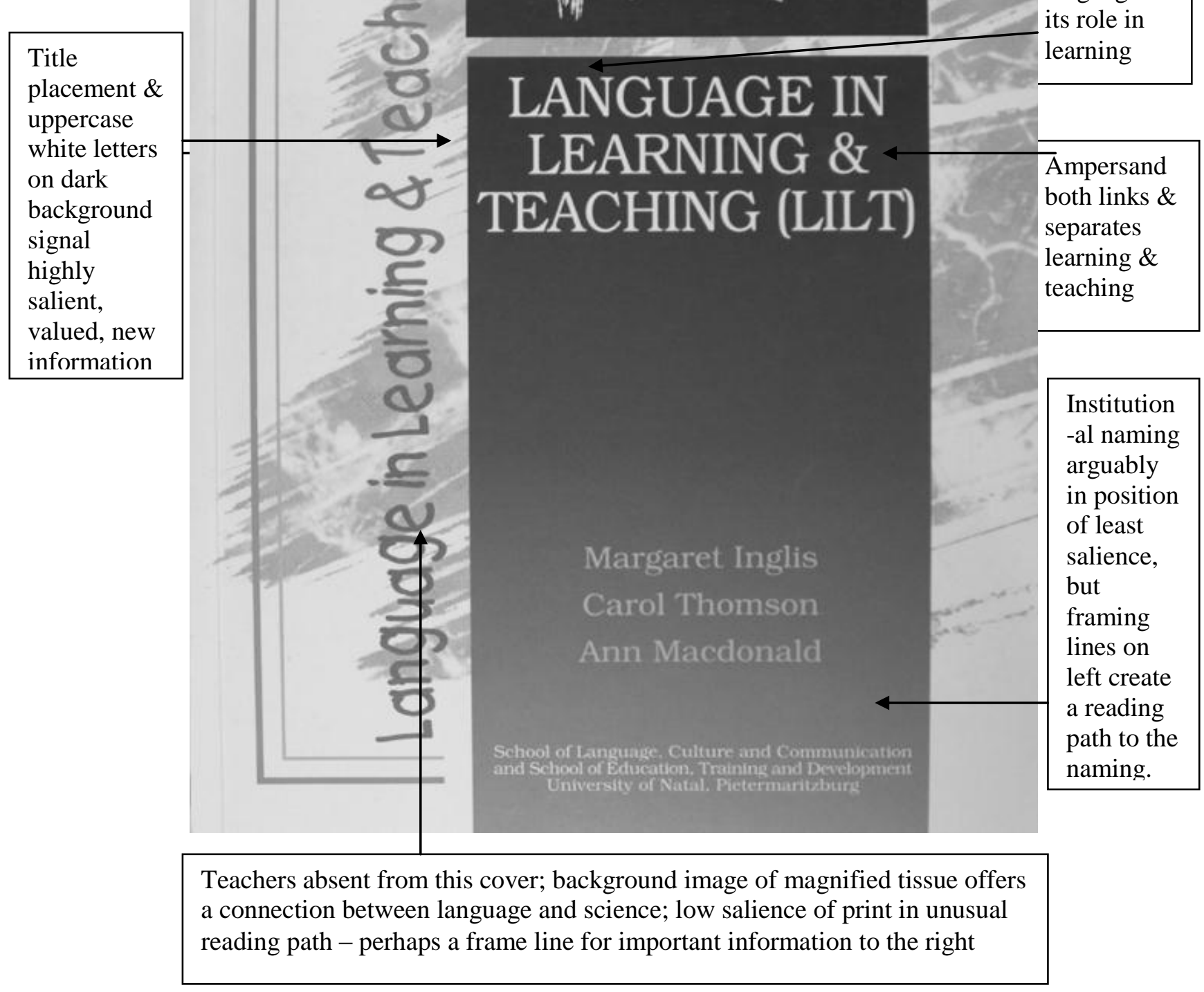




\section{Figure 7: The back cover of Learners and Learning}

\section{SAIDE OXFORD \\ Learning Guide}

High modality in questions: answers demanded from teachers/the text. Teachers constructed as active learners with interest in learning theories and in classroom practice that is grounded in case studies

How do learners move from the known to the unknown? What is the significance of school learning? What is the role of the teacher in producing and improving learning? Leamers and Learning is the fourth module in the Study of Education series, and it aims to enable teachers to analyse learning and reflect on what they can do to improve it. It draws on the learning theories of various writers, including Piaget and Vygotsky, and grounds these in examples, practical exercises. and case studies drawn from schools. This module includes an interactive Learning Guide, a Reader, and an audiotape.

The Study of Education series is a project of the South African Institute for Distance Education (SAIDE). Aimed at formal and informal teacher education, this series presents valuable open-learning materials for use in distance education or in face. to-face teaching. Intended for use in colleges of education at diploma level these modules may also be used with additional readings in higher or postgraduate diploma courses

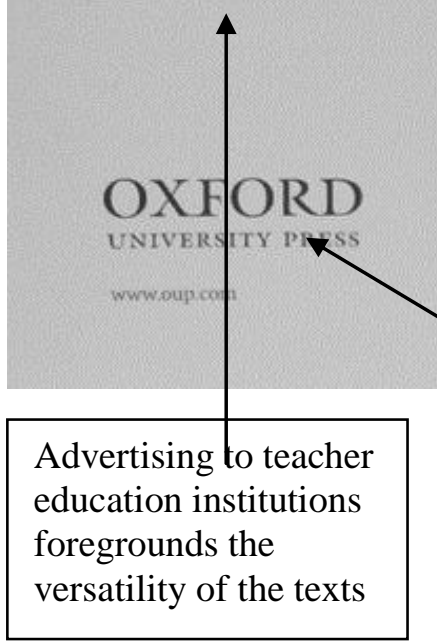

and




\section{DISCUSSION}

The covers fulfil both similar and different ideational functions - functions of representing 'the world around and inside us', and similar and different interpersonal functions - through the projection of particular social relations between the designers/producers, the reader/viewer and the object represented (the course book) (Halliday, 1985; Kress \& van Leeuwen, 2006).

Language in Learning and Teaching (LILT) was initially designed as part of a Bachelor of Education Honours programme for in-service teachers. It was subsequently published commercially by Natal University Press and has been marketed throughout the country. It is an example of in-house teaching material which, as a result of its transformation into a commodity, includes a blurb on its back cover which markets the text to a national readership. A number of the design features on its thick, glossy card covers are characteristic of a generic course book. On the front cover, the most salient feature is the drawing of a mortar board. The choice and positioning of this symbol of academic success suggests that the designers have imagined teacher-learners who will value the social status and economic benefits arising from successful completion of a course of study. Findings from a case study of teacher-learners' responses to this module support this conceptualisation of what teachers most value (Thomson, 2001). The mortar board is identifiable but disembodied - not linked to a male or female, younger or older, 'black' or 'white' figure. It suggests that while the designers have conceptualised teacher-learners as participants in an academic community of practice, they have also imagined them as students with many different individual and collective identities (Cazden, 2000) which it would be difficult to include on a single page.

The tassle on the stylised mortar board leads the eye from the symbol of success to the key word 'Language' in the module title: to earn this reward teacher-learners must focus on language. While the word 'Teaching' appears as the final word in the title, there is no visual representation of teachers on this front cover: it is teachers' membership of an academic community that is foregrounded (privileged).

The discourse of the back cover blurb is in stark contrast to the front cover image. For the most part it is addressed to teachers, rather than to students in the academy, though there is reference to 'drawing on South African and international research' in order to offer 'a sound theoretical foundation' for practice. In the most salient paragraph, a series of questions demands a response, from readers as teachers, to some of the current debates in the field of language and learning: 'Should we allow learners to use their home languages? Can we be science or mathematics teachers and language teachers? Should foundation level learners be encouraged to develop a mastery of English as the language of learning before they have developed literacy in their home language?'

The regulative pedagogic discourse (Bernstein, 1996) in the first sentence of the first paragraph constructs 'learners in South African schools' as deficient: they 'lack' both communication skills and the specialist discourses of 'particular learning areas'. Though teachers are constructed as responsible for addressing these 'deficiencies', it could be argued that the next paragraph also constructs them in deficit terms. In order to assist learners they need 'to develop an informed understanding of how learners use language for thinking and learning' and of how they 'can facilitate the development of communicative skills'. Even though the teachers registered for this module already have academic and professional qualifications, the designers have not used words such as 'extend' or 'further develop'. 
While what is arguably a deficit discourse continues in the third paragraph - teachers are imagined as needing a 'foundation' for their work, as needing to use the examples of learning strategies and activities 'provided' and as needing to 'think more deeply' than they have been doing about the role of language in their work - such deficit positioning may be accepted because the designers use the pedagogic discourse (Bernstein, 1996) of outcomes-based education. This discourse is part of the post-apartheid project of 'reinventing' the nation (Janks, 2000:175) to which the majority of South Africans subscribe. Examples of this 'new' discourse on the back cover of Language in Learning and Teaching are 'learning areas' (which have replaced school subjects), 'learner-centered approach', 'learning outcomes' and 'facilitate'. Teachers who are eager to reject the apartheid past in education and to embrace what education policy and curriculum documents construct as new, may respond positively to this constitution of them both as 'beginners' who will be assisted to become competent and as people with important responsibilities. In Bourdieu's terms, a discourse which, in part, constitutes teachers as deficient may nevertheless be socially acceptable at a particular time in the educational and political history of the country. While the pages between the covers are not the focus of this article, analysis of these pages suggests that the dominant discourse is a hybrid one. In some sections of the text readers are constituted as novices (as students in the academy, or as teachers, or both) and at others as experienced professionals.

Umthamo 1, Communication is the first booklet in a series designed and produced by the University of Fort Hare (UFH) for a teacher upgrading, in-service Bachelor of Primary Education degree. Umthamo means 'bite-sized chunk' in isiXhosa - the main language of the Eastern Cape region in which the university is located - and was chosen to reflect the decision to produce a series of 36 or 48-page, 'chewable' booklets for each module rather than one longer text. The booklets have been commercially printed by a local printing firm (L Harry and Sons) and include colour photographs on the front covers. For most booklets there are also colour photographs on the back covers, in addition to printed quotations from a range of academic texts.

In contrast to the generic covers of Language in Learning and Teaching, the front cover of Umthamo 1, Communication, which is printed on thin card with a matt surface, presents the first module, in a course of four years of part-time study, as grounded in the local and familiar. Its isiXhosa title offers reassurance that the text is manageable ('chewable') and classroom teaching and learning are foregrounded in photographs of classrooms with which teachers are likely to identify. One finding from research on the impact of the UFH programme on teachers' perceptions of their practice, is that its focus on 'context and culture $\ldots$ is seen as significant by all teacher-learners in challenging and motivating different ways of thinking about their teaching, learning and their practice' (Devereux \& Amos, 2005:277). The highly salient placement of the names of the university and the provincial department of education give authority to the text.

Kress and van Leeuwen hypothesize that an image positioned in the top left quadrant of a page offers ideal, highly valued, given information. In the photograph in this position on the front cover of Umthamo 1 the viewer's gaze is drawn first to the teacher, standing in the centre of the frame and then to the learner presenting her work to the class, at whom the teacher and most other learners are gazing. It could be argued that the designers have chosen to represent as ideal and valued, but not entirely new to teachers, a classroom scene in which the teacher plays the role of facilitator in a learner and learning-centred class. In each of the other three overlapping photographs the learners' gaze is on one another or on the work in which they are engaged collectively. As pointed out by van der Mescht (2004), the reader 
views the learners from a teacher's distance. On this cover the strong colours in the photographs and the space they occupy on the page give much greater prominence to the visual than the verbal elements in the design. Read together, the four images position teachers as classroom-based and receptive to two of the dominant themes in the new education policy and curriculum documents: (i) learner-centred classrooms; (ii) the teacher as facilitator of learning. This positioning is interesting in view of the argument developed by Jansen (2003:122) that the image of teachers as facilitators presented in policy documents has led

... ironically, to the systematic disempowerment of teachers working under conditions where familiar 'props' were dismantled at the very time that new professional demands were being made of teachers in the classroom.

The choice of a male teacher to 'represent' the profession (a choice also made for the front cover of Learners and Learning) is both somewhat curious and extremely telling, given that the majority of primary school teachers are female.

The mirror imaging of design elements on the front and back covers of Language in Learning and Teaching creates a 'wrap around' effect which could suggest to teachers that a particular selection of knowledge is 'contained' within. In Umthamo 1 there is one element of continuity between the front and back covers in that a detail from the photograph positioned in the top left quadrant on the front cover has been enlarged and printed faintly as a background to the print. However, on the back cover the local and familiar is backgrounded and the global is foregrounded in the form of a quotation from the work of international teacher education experts who appeal to the authority of research findings in support of their directives to teachers. The regulative discourse which, according to Bernstein (1996) is dominant in pedagogic discourse, constitutes particular subject positions for teachers to take up: teachers must recognise the importance of their non-verbal communication and act responsibly in this regard. The choice and positioning of this quotation suggests that the designers have imagined teachers who, on completion of the module, will be receptive to a quotation which sums up much of its content and which positions them as part of an international professional community which holds a particular view on non-verbal communication. Alternatively, as suggested by one of the reviewers of this article, the quotation could be interpreted as an example of a deficit construction of teachers as unable to recognise what is important without this being spelled out to them

\section{Learners and Learning}

This course book is one of a series prepared for the South African Institute of Distance Education's Study of Education project. SAIDE offers support to all providers of distance education in South Africa and increasingly to providers in other African countries and other parts of the world. Unlike course books which have originated in particular universities, the books in this series have been designed as source materials for formal and informal, preservice and in-service teacher education at a range of levels. The series has been co-published by SAIDE and Oxford University Press and as with Language in Learning \& Teaching (LILT), the back cover of each one focuses on marketing.

On the thick, glossy card front cover of Learners and Learning, words are the most salient feature: course title, publishers, writers and editor. On the back cover, the endorsements of a previous module in the same series, made by two newspapers published for teachers are in the position of highest salience in terms of both position and the choice of white lettering on dark 
purple background. The back cover markets the Study of Education series as a whole, a previous generic module and the current module to two broad-based constituencies: (i) individual teachers and (ii) institutions that offer teacher education programmes at several levels.

On the front cover, the choice of title, its placement on the page and the representation of active learners with their teacher in the physical space of a facilitator, position readers as teachers who acknowledge that the learner rather than the teacher is 'centre stage' in the new outcomes-based curriculum for South African schools. In this respect it is similar to the front cover of Umthamo 1, Communication. However, the choice of a generic line drawing rather than photographic images of identifiable learners and their teacher in a particular context, suggests that the designers have imagined a readership of teachers who are or will be working in a range of contexts - a text for national rather than local/regional use. Several vectors in the image (the pointing arm of the teacher and of one of the learners, and the movement of the learners who carry scaffolding) direct the gaze of the reader to 'the outcome': knowledge under construction. It seems that the designers have imagined readers who are familiar with the concept of scaffolding both in relation to the construction of buildings and in relation to the construction of knowledge.

Throughout the Study of Education series the term 'Learning Guide' is used to distinguish the core study material from an accompanying Reader. The choice of the noun 'guide' and the adjective 'interactive' to describe it on the back cover blurb also constructs for teachers the possibility of responding to the text in a variety of individual ways. While the back cover of the LILT module is heavy with nominalizations such as 'an informed understanding' and 'a sound theoretical foundation' in the description of what the module offers, on the back cover of Learners and Learning the designers use mental and material process verbs (Halliday, $1985)$ to describe what they hope the module will achieve. They focus on 'action': the module aims to enable teachers to 'analyse learning and to reflect on what they can do to improve it' (italics added for emphasis).

In the pedagogic discourse on the back cover of Learners and Learning neither learners nor teachers are constituted in deficit terms. As on the back cover of Language in Learning and Teaching (LILT), the introduction to the Learners and Learning module begins with a series of demands on readers in the form of questions to be answered. However, unlike those on the LILT cover these questions are oriented to what might be termed 'academic enquiry': 'How do learners move from the known to the unknown? What is the significance of school learning? What is the role of the teacher in producing and improving learning?' The statement that the module 'draws on the learning theories of various writers, including Piaget and Vygotsky, and grounds these in examples, practical exercises, and case studies drawn from schools' suggests that the designers imagine readers who are interested in theory and in praxis. By constructing the latter part of the advertisement for the module to appeal to teacher-educators as well as students (pre-service and in-service teachers) the designers foreground the academic community of practice into which students are to be initiated.

To conclude the discussion, Table 1 summarises some of the meanings foregrounded, backgrounded or absent on the three sets of covers. 
Table One: Meanings foregrounded or backgrounded in three sets of covers

\begin{tabular}{|l|l|}
\hline Front cover & Back cover \\
\hline $\begin{array}{l}\text { LILT: Foregrounds academic success } \\
\text { (mortar board in highly salient position) }\end{array}$ & $\begin{array}{l}\text { Advertises the module and others in the } \\
\text { programme; focuses on in-service } \\
\text { and foregrounds the role of language in } \\
\text { teachers with professional responsibilities } \\
\text { learning; teachers are absent, though } \\
\text { teaching is the final word in the title; } \\
\text { writers and university are named but not } \\
\text { deficit terms as needing to learn; as these } \\
\text { constructions are located in current policy } \\
\text { discourses they may nevertheless be } \\
\text { acceptable to teachers; the academy is } \\
\text { backgrounded, though there are some } \\
\text { references to research and to theory }\end{array}$ \\
\hline $\begin{array}{l}\text { Umthamo 1: Foregrounds learner-centred } \\
\text { learning, facilitated by the teacher, in } \\
\text { familiar local contexts; the university and } \\
\text { the provincial education department are } \\
\text { also foregrounded }\end{array}$ & $\begin{array}{l}\text { Quotation from an academic authority } \\
\text { positions teachers to respond to main } \\
\text { ideas in the course book in a particular } \\
\text { way; no direct reference to the academy } \\
\text { and no advertising. (These booklets are } \\
\text { not commercially available). }\end{array}$ \\
\hline $\begin{array}{l}\text { Learners and Learning: foregrounds the } \\
\text { module title and the publishers; learner- } \\
\text { centred knowledge construction is present } \\
\text { in an image of medium to low salience; a a }\end{array}$ & $\begin{array}{l}\text { Advertises the module and others in the } \\
\text { programme - (praise from teacher } \\
\text { newspapers in position of high salience); } \\
\text { 'generic' male teacher is a marginal } \\
\text { presence }\end{array}$ \\
$\begin{array}{l}\text { situates modules within current policy; } \\
\text { constructs teachers as playing active, } \\
\text { important roles in classroom learning- } \\
\text { perhaps subtly co-opting "ideal" readers; } \\
\text { refers to key academic theorists and to } \\
\text { theorised practice }\end{array}$ \\
\hline
\end{tabular}

\section{CONCLUSION}

In writing about policy images and teacher identity in South African classrooms, Jansen refers to a point made by curriculum theorist Buenfil-Burgos: 'while policies might not change what happens inside classrooms, they nevertheless "leave a trace in practice"' (Jansen, 2003:128). I argue that while course books designed for pre-service and in-service teacher education differ from policy documents, they also leave traces in the identities of readers as students in the academy and as teachers in classrooms. In South Africa, more pre-service and in-service teacher education students are enrolled in distance learning than in on-campus programmes (Glennie, 2003). Print is still the most widely used medium for mediating the distance between these students and the designers of course materials and the covers of these materials may be their first point of contact with a particular module ${ }^{3}$. How they imagine themselves within the academic and classroom communities of practices (Lave \& Wenger, 1991) constituted in the visual and linguistic designs of these covers may influence readers' subsequent 'investment' (Kanno \& Norton, 2003) in their academic studies and professional practice. While empirical research with teachers would be needed in order to understand how they read course materials and themselves, the analysis offered in this article suggests that readers as students and as teachers have been imagined quite differently in the designs of each set of covers. 


\begin{abstract}
END NOTES
${ }^{1}$ Materials from the University of Natal's B Ed programme were highly commended in the inaugural National Association of Distance Education Organisations of South Africa (NADEOSA) awards for excellence in distance education in 2000. The University of Fort Hare won the NADEODSA award for excellence in 2005.

${ }^{2}$ For example, Alan Tait from the UK Open University wrote the following on the occasion of SAIDE's tenth anniversary in 2002: 'SAIDE's fearless work has lit a torch for educational opportunity for all, in conjunction with the most effective of contemporary approaches to distance education. The work has not only been notable within South or even Southern Africa, but has a reputation world-wide for the impact it has made.'

When teachers enrolled in the University of Fort Hare's B Prim Ed programme receive a new umthamo at a Saturday tutorial session, they are asked to examine the covers in order to predict what the module will be about (personal observation of tutorials, 2001)

${ }^{3}$ When teachers enrolled in the University of Fort Hare's B Prim Ed programme receive a new umthamo at a Saturday tutorial session, they are asked to examine the covers in order to predict what the module will be about (personal observation of tutorials, 2001).
\end{abstract}

\title{
REFERENCES
}

ADLER, J. 2002 Global and local challenges of teacher development. In Adler, J \& Y Reed (Eds), Challenges of teacher development. Pretoria: Van Schaik.1-16.

ALDER, D. 2004. Visual identity texts: A case study in the English classroom. Unpublished BA honours research report, University of the Witwatersrand, Johannesburg.

BERNSTEIN, B. 1996. Pedagogy, symbolic control and identity. London: Taylor \& Francis.

BOURDIEU, P. 1991. Language and symbolic power. Oxford: Polity Press.

CAZDEN, C. 2000. Taking cultural differences into account. In Cope, B. and M. Kalantzis (Eds), Multiliteracies. South Yarra: Macmillan.249-266.

DEVEREUX, J \& S Amos. 2005. The University of Fort Hare's learner-centred distance education programme. Open Learning. 20 (3):277-284.

FOUCAULT, M. 1990. The history of sexuality. New York: Vintage Books.

GLENNIE, J. 2003. Working together to maximise the role of distance education in higher education in South Africa - a report back on the research done for the Council on Higher Education. Keynote address, NADEOSA Conference, Johannesburg, 27 August 2003.

GULTIG, J. (Ed), 2001. Learners and learning. Johannesburg \& Cape Town: SAIDE and Oxford University Press.

HALLIDAY, MAK. 1978. Language as a social semiotic: The social interpretation of language and meaning. London: Edward Arnold. 1985. An introduction to functional grammar. London: Edward Arnold.

INGLIS, M, C THOMSON \& A MACDONALD. 2000. Language in learning \& teaching. Pietermaritzburg: University of Natal Press.

JANKS, H. 2000. Domination, access, diversity and design: A synthesis for critical literacy education. Educational Review. 52(2):175-186.

KANNO, Y \& B NORTON. 2003. Imagined communities and educational possibilities: Introduction. Journal of Language, Identity and Education. 2(4):241-249.

KRESS, G \& T VAN LEEUWEN. 1996. Reading Images: The grammar of visual design. First Edition. London \& New York: Routledge. 
KRESS, G \& T VAN LEEUWEN. 2006. Reading images: The grammar of visual design. Second Edition. London \& New York: Routledge.

LAVE, J \& E WENGER. 1991. Situated learning: Legitimate peripheral participation. Cambridge: Cambridge University Press.

LEA, M. 2005. 'Communities of practice' in higher education: Useful heuristic or educational model? In Barton, D \& K Tusting (Eds), Beyond communities of practice. Cambridge: Cambridge University Press.180-197.

LILLIS, T \& C MCKINNEY. 2003. Analysing language in context: A student workbook. Stoke on Trent: Trentham Books and The Open University Press.

MACKEN-HORARIK, M. 2004. Interacting with the multimodal text: Reflections on image and verbiage in Art Express. Visual Communication, 13(1):5-26.

MARTIN, J \& D Rose. 2003. Working with discourse. London and New York: Continuum.

SIMON, R. 1992. Teaching against the grain. Toronto: OISE Press.

THOMSON, C. 2001. Writing experiences of B Ed honours students registered for the Language in Learning and Teaching (LILT) module: A case study. Unpublished MA research report, University of Natal, Pietermaritzburg.

THREADGOLD, T. 2001. Making theories for different worlds: Making critical differences. In Freebody, P, S Muspratt \& B Dwyer (Eds), Difference, silence and textual practice. Cresskill(NJ): Hampton Press.209-242.

UNIVERSITY OF FORT HARE DISTANCE EDUCATION PROJECT. (1998) Umthamo 1 communication. University of Fort Hare.

VAN DER MESCHT, C. 2004. Creating a relationship: a discourse analysis focusing on the construction of identities and relationships in distance education materials for a teacher upgrade programme. Unpublished M Ed research report, Rhodes University, Grahamstown.

\section{BIOGRAPHIC NOTE}

Yvonne Reed is head of Applied English Language Studies in the School of Education at the University of the Witwatersrand. Her research interests include critical pedagogic analysis of teacher education course books and of school textbooks designed and produced for English and African languages. (Email: yvonne.reed@wits.ac.za). 